\title{
The Impact Of The National Credit Act On Residential Mortgage Lending In South Africa
}

\author{
Catherine Boonzaaier, University of South Africa, South Africa \\ Joseph Chisasa, University of South Africa, South Africa
}

\begin{abstract}
The purpose of the study reported in this article was to determine the impact of the National Credit Act on residential mortgage lending in South Africa. The National Credit Act (NCA) was promulgated and implemented on 1 June 2007. The purpose of the NCA was to remove the many unfair practices, inappropriate disclosure and anti-competitive practices from the market and to achieve honesty in the credit market. Low-income groups were held back because they could not gain access to formal finance to build or improve houses or supplement housing subsidies to get bigger houses. This study applied a quantitative research design using monthly time series secondary data for the period January 2001 to August 2011. The statistical analysis techniques used in this study were t-tests, descriptive statistics, trend analysis and correlation analysis. It was found that the NCA had a positive effect on the residential mortgages in South Africa. These results have policy implications on the continued regulation of the credit market and the avoidance of reckless lending.
\end{abstract}

Keywords: Banks; Credit; National Credit Act; Regulation; Residential Mortgages

\section{INTRODUCTION}

n 1994, South Africa attained political independence from a regime that discriminated and thus disadvantaged the majority of its population. One of the areas in which South Africans were disadvantaged was access to decent accommodation due to the non-availability of mortgage finance. However, the dawn of democracy ushered in more players in the credit market. Some lenders could not cope with increasing competition for clients. As a result of the stiff competition, normal affordability tests were neglected, leading to many borrowers defaulting. To curb the increase in defaulting borrowers, government introduced the National Credit Act in 2007. The aim of the NCA is to protect consumers from reckless lending.

The dysfunctional credit market was based on various problem areas (Goodwin-Groen \& Kelly-Louw, 2006, p. 12). The problem areas were fragmented and outdated legislation, ineffective consumer protection, high cost of credit, rising levels of over-indebtedness and reckless behaviour by credit providers (Department of Trade and Industry (DTI) 2004b). The National Credit Act (NCA) replaced the Credit Agreements Act 75 of 1980 and the Usury Act 73 of 1968. Even though the NCA was approved in March 2005, it was only implemented in June 2007 (Whittaker, 2008, p. 571). Gabriel Davel (2006), head of the Microfinance Regulatory Commission (MFRC), said the NCA is "consistent in its application, transparent and shifts rights to the consumer" (Whittaker, 2008, p. 571). During 1968, the consumer credit market was influenced by a range of political, social and economic changes (Goodwin-Groen \& Kelly-Louw, 2006, p. 12).

Improper legislation, whether the Usury Act, Credit Agreements Act or debt collection procedures in the Magistrate's Courts, Act 32 of 1944, and a need of enforcement all added to the improper state of affairs (Goodwin-Groen \& KellyLouw, 2006, p. 13). The increasing use of credit by low-income groups also added to the need for a closer examination of the credit legislation (Goodwin-Groen \& Kelly-Louw, 2006, p. 12). The purpose of this article is to determine the impact of the NCA on residential mortgage lending in South Africa. The study is motivated by the increasing level of household debt in the aftermath of the introduction of the NCA. Specifically, this study examined the impact of the 
NCA on residential mortgage financing by South African banks. Furthermore, the study sought to inform the borrowing public of the prevalence of reckless credit granting tendencies of some of the credit institutions and the protection available to them via invoking the NCA. On the other hand, financial institutions will make informed decisions when allocating finance for housing to borrowers.

This article is structured as follows. The literature underpinning this study is discussed in Section 2. Section 3outlines a description of the research methodology which was applied for the study. The results are presented and discussed Section 4 while Section 5 concludes the study.

\section{LITERATURE REVIEW}

\section{Background of the National Credit Act (NCA)}

Section 3 of the National Credit Act states:

"The purpose of this Act is, to promote and advance the social and economic welfare of South Africans; promote a fair, transparent, competitive, sustainable, responsible, efficient, effective and accessible credit market and industry; and to protect consumers" (Goodwin-Groen \& Kelly-Louw, 2006, p. 43).

Before the promulgation of the NCA, the granting of credit by financial institutions to consumers was approved without properly investigating whether the consumer will be able to repay the debt or not. The NCA was announced and implemented on 1 June 2007. Previously there was a discrepancy of power between the consumers and the credit providers because of low education, a lack of information by consumers, weak disclosure and deceptive marketing practices. Many South African consumers completed unaffordable credit contracts which led to many social problems (Stoop, 2009, p. 366). This led to the implementation of the NCA.

The NCA replaced the Credit Agreements Act 75 of 1980 and the Usury Act 73 of 1968, and it is important to understand why they were replaced (Mould, 2008, p. 110). According to Mould (2008, p. 110) "some legislation protects consumers, while other legislation has a broader application-field". The Usury Act was first implemented in 1968 in South Africa during the apartheid era, and this Act excluded financial support to the non-white people, especially the black people, and had serious concerns (Whittaker, 2008, p. 570). The Minister of Trade instituted a Usury Act Exemption in 1992, which allowed lenders to charge unregulated interest rates on small loans in order to stimulate growth in lending to micro, small, and medium-sized enterprises (Whittaker, 2008, p. 570). The Credit Agreement Act and Usury Act protected consumers up to a certain amount of debt, but when these debts exceeded the "ceiling" for the relevant legislation's field of application, the extended credit (debt) was no longer considered consumer credit (Mould, 2008, p. 110). According to (Stoop, 2009, p. 373), The Department of Trade and Industry (DTI) would like South Africa's credit policy to address consumer education at the levels of adult education and school learners by providing institutional and financial support to them. This will ensure that South African consumers will be more knowledgeable about risks attached to credit and will make good choices (Stoop, 2009, p. 373).

The microlending sector focused more on the urban employed individuals, instead of improving credit access to the poor, rural South Africans (Whittaker, 2008, p. 570). It created a disaster by "dividing the market and thereby excluding lower income people from the banking sector and formal credit actions" (Whittaker, 2008, p. 570). In the mid-1990s, the Minister of Trade and Industry, Alec Erwin, noticed that poor and low-income South Africans were being charged unfair high interest rates, and he threatened to withdrawal the 1992 Exemption overall (Whittaker, 2008 , p. 570). The main purposes of the NCA are to promote a fair, competitive, accessible, equitable credit market (Mould, 2008, p. 112). On 13 October 2005, the Minister of Trade and Industry addressed the National Assembly stating that the "market was characterised by a lack of transparency, limited competition, high costs of credit and limited consumer protection", and mentioned that there is a need for a credit act where the information should be plain and in an understandable language (Mould, 2008, p. 111). Thus, the aim of the new NCA is to protect the consumers against reckless lending. 


\section{Housing Financing in South Africa}

"Everyone has the right to a standard of living adequate for the health and well-being of himself, and of his family, including food, clothing, housing, medical care, necessary social services, the right to security in the event of unemployment, sickness, disability, widowhood, old age or other lack of livelihood in circumstances beyond his control." (United Nations, 1948; Le Roux, 2011, p. 6). In general, people want security and for their basic needs to be provided for.

The importance of housing as a vital need and as a component of the economy cannot be over-emphasized because it is predicted that on average between $15 \%$ and $40 \%$ of household monthly expenditure is spent on housing and housing services (Okpala, 2012, p. 182). According to Kajimo-Shakantu \& Evans, (2006, p. 24), housing also represents approximately $2 \%$ to $10 \%$ of the Gross Domestic Product (GDP) in some developing countries.

A number of different models for housing finance systems exist and in practice the majority is centered on the banking system, either directly or indirectly (Boleat, 2003, p. 4). Most of the low-income groups experience barriers in accessing financing to meet their housing needs (Kajimo-Shakantu \& Evans, 2006, p. 24). There is a difference between the demand requirements, looking at the poor households and the supply requirements of the formal finance sector (Kajimo-Shakantu \& Evans, 2006, p. 24), for instance, loan size, period of loan repayment, consistency of the principal repayments, the language used for writing loan conditions and an acceptable form of security (KajimoShakantu and Evans, 2006, p. 24). Mortgage lending is simply a special type of bank lending and it will be foolish to disregard this from the housing finance system because in most countries they are the most important lenders (Boleat, 2003, p. 4). Credit Agricole is the largest lender in France and the savings banks are the biggest lenders in Germany and the commercial banks, directly and indirectly in America are amongst the largest lenders (Boleat, 2003, p. 4).

The housing finance in South Africa is largely determined by two factors, which include cost of funding and the risk of lending in the different markets (Kajimo-Shakantu \& Evans, 2006, p. 24). Low-income groups are held back because they cannot get access to formal finance in order for them to build or improve houses, or supplement housing subsidies to get bigger houses (Kajimo-Shakantu \& Evans, 2006, p. 24). The majority of the low-income households in South Africa is dependent on government for house subsidies, but the value of the subsidy declined and complicated the approval and payout mechanism (Kajimo-Shakantu \& Evans, 2006, p. 25). Banks are reluctant to operate in the low-income group housing market, and this unwillingness causes a shortage problem in the country (Kajimo-Shakantu \& Evans, 2006, p. 26). Whereas the high and middle-income groups are provided for, the banks, especially the larger banks have little engagement with the low-income groups (Kajimo-Shakantu \& Evans, 2006, p. 26).

Housing in South Africa has a long history of government interference, characterised by the post-apartheid drive towards private ownership via public provision (Lemanski, 2012, p. 337). South Africa's housing landscape is deeply influenced by apartheid, and that is why the present cannot be fully understood without grasping the past (Lemanski, 2012, p. 337). Since the late 1980s, South Africa sought ways to broaden housing finance to low-income households and during this period, housing finance institutions were looking for ways of supporting borrowers in the low-income market including risk mitigation, acting as guarantors and as wholesale providers (Tomlinson, 2007, p. 78). The majority of the low-income group depends on the subsidies from the government. During 1992, consensus around a new non-racial housing policy was formulated and created by a multi-party body, the National Housing Forum (NHF) (Tomlinson 2002, p. 8). According to Tomlinson (2002, p. 8), fierce debates followed on whether housing should be delivered by the state or the market; whether the standard of the house should be a "four-roomed house" or "progressive" and how to draw back the financial institutions, which were previously forced out due to bond boycotts and the wildly fluctuating economy in South Africa.

The first democratic election in South Africa was in 1994 and it inherited a backlog of, 1.2 to 2.5 million houses. This inherited backlog was the product of the history of apartheid, unemployment and poverty (Pillay \& Naude, 2006, p. 873). Since 1994, government promised to build 1 million houses for the low-income households. Providing housing for the poor was their main concern (Lemanski, 2012, p. 337). The African National Congress (ANC)-led government uses the subsidy scheme to support the development of black entrepreneurs and does not want to depend on the old "apartheid" construction (Gilbert, 2004, p. 23). The government desperately involved the banks to finance the low- 
income groups when they realised that they lacked the capacity to finance the ambitious subsidized housing scheme (Gilbert, 2004, p. 23). Policy reforms also ensued.

The house policy was formed during 1992 to 1993 to draw financial institutions back into developing the black housing market, which they had escaped in the early 1990s (Tomlinson, 2007, p. 78). Between 1994 and 1997, the demand for houses increased from 2.5 million to 3 million households (Pillay \& Naude, 2006, p. 873). In 1994 an estimated 20\% of the new lending was not performing and banks discontinued the lending (Porteous, 2005, p. 34). Banks provided home loans to the low-income groups and to the moderate-income groups of South Africa (Pillay \& Naude, 2006, p. 873). Since the end of apartheid in 1994, the main objective of the national housing policy has been the provision of credit for low-income groups by increasing the engagement with banks in the high-risk, low-income housing finance sector (Freybote \& Karoly, 2008, p. 185). In 1994, it increased to R12 500, but over time the subsidy increased to R31 879 as described in Table 3 (Tomlinson, 2007, p. 78). In 1994, 34000 properties were owned by the banks and the state-owned mortgage lender Khayalethu Home Loans, as a consequence of non-performing loans (Pillay \& Naude, 2006, p. 873). This caused the lenders to withdraw from the low and moderate income group because of their incapability to remove home owners that could not pay for their houses (Pillay \& Naude, 2006, p. 873). People who earned between R1501-R2500 per month received $8 \%$ and those that earned less than R3500 per month, received the outstanding balance (Pillay \& Naude, 2006, p. 873). The housing policy of South Africa states that in order to offer a satisfactory standard of housing to low-income households who earn less than R3 500 (US\$580) per month, affordable housing financing is needed (Tomlinson, 2007, p. 77). While early houses were as small as $25 \mathrm{~m}^{2}$, subsidy houses are now a minimum of $30 \mathrm{~m}^{2}$ after 1998 and these houses are known as Reconstruction and Development Programme houses (from the 1994 RDP) (Lemanski, 2012, p. 337).

The 2004 Breaking New Ground (BNG) was announced, due to the failure of the National Housing Subsidy Scheme to solve South Africa's housing shortage with adequate quality (Lemanski, 2012, p. 339). BNG encourages propertyownership as a poverty-alleviating asset for wealth creation and empowerment by seeking to produce settlements that are viable, unlike the previous RDP that concentrated on mass delivery of end products, i.e. a house (Lemanski, 2012, p. 339). Government intervenes in housing markets due to the negative externalities caused by conflict between the objectives of the borrowers and investors (Flanagan, 2012, p. 507).

Kajimo-Shakantu and Evans (2006, p. 24), identify four basic models of housing finance as shown in Table 1. Most of the low-income groups experienced barriers in accessing financing to meet their housing needs (Kajimo-Shakantu and Evans, 2006, p. 24). There is a difference between the demand requirements, looking at the poor households and the supply requirements of the formal finance sector (Kajimo-Shakantu and Evans, 2006, p. 24); for instance, loan size, period of loan repayment, consistency of the principal repayments, the language used for writing loan conditions and an acceptable form of security (Kajimo-Shakantu and Evans, 2006, p. 24). Section 63 of the NCA states that a consumer has the right to receive any document in terms of this Act in "an official language that the consumer reads or understands" (Mould, 2008, p. 115). It is fair to presume that when the consumer signed the credit agreement in case of home loans, provided that the necessary information was supplied by the credit provider, that the agreement is understood by the consumer (Mould, 2008, p. 115).

The credit provider must give a quotation and a statement when the credit agreement is concluded. The reason for the quotation is for the consumer to compare the agreement to other credit providers in order to get a better deal (Mould, 2008, p. 115). Section 92 of the NCA lays responsibility on the credit-provider to supply the necessary details of the "Pre-agreement disclosures", to the consumer when they go into a credit agreement (Mould, 2008, p. 115). These details include the following; the amount of the credit provided, the installments made, interest rate, the initiation fee, deposit needed, credit insurance and the service fee available (Mould, 2008, p. 115). An example will be where the consumer is informed who applied at the financial institution for a loan to buy a home, but the conveyancer is responsible for registering the subsequent bond in the Deeds Office and not the financial institution (Mould, 2008, p. 115). This is due to the fact that the financial institutions explained to the conveyancer in detail what the credit agreement entails, and that the conveyancer must also explain to the consumer what is expected from them in terms of the agreement (Mould, 2008, p. 115). When the consumer understands the details of the agreement and signs it, a valid contract is created. Pillay and Naude (2005) and Kajimo-Shakantu and Evans (2006) came to the conclusion that the banks are reluctant to finance houses in the low-income households and this becomes an obstacle because it contributes to the housing shortage in the country. However, a review of the global financial crisis of 2008 provides 
insights into the risk inherent in mortgage lending and explains why South Africa's formal financial institutions have a low risk appetite for mortgage lending to low-income households.

Table 1. Basic models of housing finance

\begin{tabular}{|c|c|c|c|c|}
\hline Model & $\begin{array}{c}\text { Revolving Credit } \\
\text { System }\end{array}$ & $\begin{array}{l}\text { Specialized Housing } \\
\text { Finance Institutions }\end{array}$ & Public Financing & Mortgage financing \\
\hline Typical examples & $\begin{array}{l}\text { Rotating savings } \\
\text { system and credit } \\
\text { Associations }\end{array}$ & Building Societies & $\begin{array}{l}\text { Organisations and } \\
\text { Parastatals }\end{array}$ & Commercial Banks \\
\hline Brief description & $\begin{array}{l}\text { Common among the } \\
\text { low-income group in } \\
\text { developing countries, } \\
\text { often supported by } \\
\text { donor agencies. Use } \\
\text { personal daily savings } \\
\text { to create a 'revolving } \\
\text { fund'. }\end{array}$ & $\begin{array}{l}\text { Common in the UK } \\
\text { (and in its former } \\
\text { colonies). Though they } \\
\text { operate like banks, they } \\
\text { mostly specialise in } \\
\text { real estate. Use savings } \\
\text { deposited by the public } \\
\text { to provide home loans. }\end{array}$ & $\begin{array}{l}\text { Common in centrally } \\
\text { planned economies } \\
\text { where public agencies } \\
\text { direct finances to } \\
\text { housing programmes } \\
\text { based on public funds. }\end{array}$ & $\begin{array}{l}\text { Common, but highly } \\
\text { constrained in } \\
\text { developing countries. } \\
\text { Use customers' short- } \\
\text { term savings (deposits) } \\
\text { to lend for housing } \\
\text { development on long- } \\
\text { term basis (typically } \\
10-30 \text { year mortgages). }\end{array}$ \\
\hline
\end{tabular}

Source: Adapted from Kajimo-Shakantu and Evans (2006, p. 24)

\section{Sub-prime Crises in the United States of America (USA)}

The term "credit-crunch" has been used to describe the decrease of credit supply in response to both, (i) decline in the value of bank capital, and (ii) conditions required by bank supervisors, regulators, or banks themselves that want banks to keep more capital than they previously would have kept (Mizen, 2008, p. 531). The "credit-crunch" had a global impact since international investors were involved. For many, the financial crisis of the United States of America started in 2007 when the Federal Reserve increased interest rates and the housing market had a set-back and home prices dropped (Stecker, 2009, p. 72). The sub-prime mortgage market gave an opportunity to homeowners and access to credit to individuals who did not qualify to take part in the conventional market (Ho \& Pennington-Cross, 2008, p.176).

According to Kolb (2011, p. 38), the occurrence of the sub-prime did not happen overnight - it took years and a great deal to lay the foundation for disaster. This foundation was associated with social indicators that were in fact quite promising and assisted in covering the shakiness of the towering debt of mortgage finance (Kolb, 2011, p. 38). The question was why the credit crunch took place and why now? This crunch was due to two developments, which took place in the late 1990s and early twenty-first century. "Firstly, the extremely tranquil macro-economic conditions (Great Moderation) together with a flow of global savings from emerging and oil-exporting countries resulted in reduced macro-economic volatility and lower long-term interest rates (Mizen, 2008, p. 533). Secondly, an expansion of securitization in subprime mortgage-assets formed sophisticated financial assets with relatively high yields and good credit ratings" (Mizen, 2008, p. 533).

According to Duca, Muellbauer \& Murphy (2010, p. 204), there were factors that contributed to the build-up and bursting of the United States housing bubble. Those factors include the role of financial innovation, over-optimism about the sub-prime and other innovations, sources of leverage and liquidity during the sub-prime and structured finance, market frictions and house price expectations, and the combination of bubble-feeding factors. According to Kashyap, Rajan \& Stein (2008), the USA was not the highest in terms of price-growths, if compared to Ireland, Spain, the Netherlands, the United Kingdom and New Zealand who had higher housing prices. The USA financial system transformed sub-prime mortgages that were historically handled by local bankers, into mortgage-backed securities with AAA-ratings which were suitable for pension funds, insurance companies, and banks around the world (Kashyap et al., 2008). The financial crisis hit a high pitch in the fall of 2008 when the investment bank Lehman Brothers, fell bankrupt (Stecker, 2009, p. 74). Merrill Lynch was acquired by Bank of America, AIG received $\$ 80$ billion from the federal government and Wachovia agreed to be acquired by Wells-Fargo (Stecker, 2009, p. 74). In the midst of all these changes, Congress issued the Emergency Economic Stabilization Act of 2008 which approved the U. S. Treasury 
Proposal for $\$ 700$ billion Troubled Asset Relief Program (TARP) (Stecker, 2009, p. 74). What is evident from the global financial crisis is that financial institutions need to prudently manage their lending portfolios.

\section{RESEARCH METHODOLOGY}

A quantitative research design was used, applying time series secondary data. The mortgage data collected and used is for household residential mortgages because mortgage lending is subject to NCA regulation. Data for monthly residential mortgages registered for the period January 2001 to August 2011 were obtained from Lightstone Data.

The population of the banks used for this study comprises of all South African banks that were registered in terms of the Banks Act for the relevant period and were legally required to send their DI/BA forms to the SARB. The results were captured and then analysed by means of the Statistical Analysis System (SAS) Enterprise Guide 4.3. The correlation analysis was carried out by using the Statistical Package for Social Science (SPSS).

The data was analysed for the period before the enactment of the National Credit Act (January 2001 to March 2005) and after the enactment of the NCA (June 2007 to August 2011). The purpose of using 2007 as the base-year was to minimize the effects of confounding factors such as external shocks that cannot be fully controlled. T-test (comparison of means), descriptive statistics, correlation analysis and trend analysis were used to analyse the data. Descriptive statistics focused on the collection and display of information (Croucher, 2010, p. 226). The t-test was used in this study to compare the effect of the NCA prior and after the implementation of the NCA. The t-test which is commonly known as the Student's t-distribution, is used to compare two sets of numbers to see whether or not they are different - even when the sets of numbers are quite small (Walker, 2010, p. 176).

\section{RESULTS AND DISCUSSION}

\section{Trend Analysis}

A trend analysis of the number of registered bonds was conducted and the results are shown in Figure 1 below. The purpose is to give an overview of the patterns of residential bond registrations in South Africa. Although bond registration was characterised by fluctuations, a general upward trend is observable from January 2001 to July/August 2007. A subsequent downward trend follows for the remaining period under review (August 2007 to June 2011).

A closer look at Figure 1 shows that there was a drop in the number of registered bonds between January and April 2001 and a steady increase thereafter. This trend could be attributed to high interest rates and high unemployment. In mid-2007, residential bond registrations dropped, coinciding with the implementation of the NCA. From 2008 the number of registered bonds declined rapidly until 2011. From the trend analysis, it is evident that there was a decrease in the number of residential bonds registered. The decrease may have been as a result of the implementation of the NCA. As such, it can be concluded that the introduction of the NCA had a positive impact on residential bonds. These results confirm observations made by Pillay $(2009$, p. 89$)$ that in the aftermath of the implementation of the NCA, a declining trend experienced in 2008 was driven by the lagged effect of the interest rate cycle, the NCA, stricter criteria by the banks and financial difficulties experienced by consumers, as demonstrated in Figure 1.

By the end of 2008, the strict contraction in nominal house price growth triggered real growth to move into negative numbers, which clearly affected the extension of new mortgage loans (Luttig, 2010, p. 20). The contraction in the mortgage market was further helped by the concerns of a recession and the changes in the lending criteria of the four major banks, with all four unwilling to lend anything more than $80 \%$ of the value of the house by the end of 2008 (Luttig, 2010, p. 20). The number of mortgages stabilised as from 2008. The number of mortgage agreements entered into grew by $12.13 \%$ for the quarter ended December 2009, but on a year-on-year basis the number of mortgage agreements entered into showed an extra decline of $28.78 \%$ (Luttig, 2010, p. 21). The majority (79.87\%) of mortgages granted benefited people with a gross monthly income greater than R15 000 (Luttig, 2010, p. 21). 
Figure 1. Total number of residential bonds registered

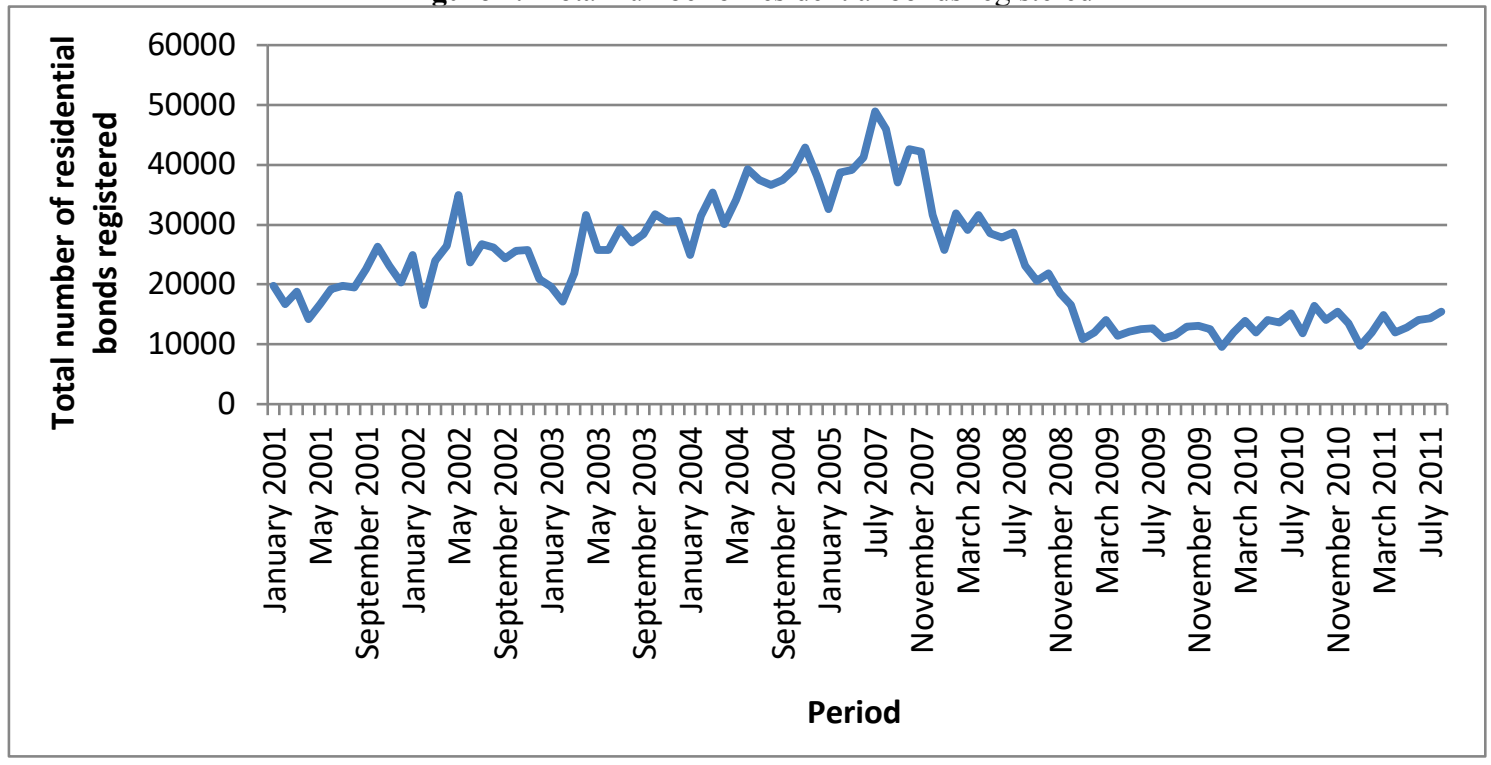

\section{Descriptive Statistics}

Descriptive statistics in Table 2 below show the means for mortgages issued in the pre- and post-NCA periods. The mean for pre NCA mortgages is 27321.1 and that for the post NCA is 19750.2. This shows that the chances for an application to be approved before the NCA was higher than in the post NCA period. The smaller the standard deviation, the closer the data lies to the mean, thus, the tighter the spread of the data is (Pieterse, 2009, p. 126). The standard deviation, which is an indication of the average distance from the mean, indicates that the standard deviation for pre NCA (7346.2) is less than post NCA (10680.5)

\section{Difference Between Means}

The study hypothesised that the means for the total number of residential bonds registered are equal. Table 2 shows that the means are not equal and the difference is statistically different $(\operatorname{Pr}<0.0001)$ at the $95 \%$ confidence level. Thus, the hypothesis of equality of means is rejected.

Table 2. Total number of residential bonds registered

\begin{tabular}{l|c|c|c|c|c|c|c}
\hline \multicolumn{1}{c|}{ V2 } & Method & Mean & \multicolumn{2}{c|}{$\mathbf{9 5 \%}$ CL Mean } & Std Dev & \multicolumn{2}{c}{ 95\% CL Std Dev } \\
\hline Pre NCA & & 27321.1 & 25255.0 & 29387.3 & 7346.2 & 6146.6 & 9131.9 \\
\hline Post NCA & & 19750.2 & 16746.3 & 22754.1 & 10680.5 & 8936.4 & 13276.7 \\
\hline Diff (1-2) & Pooled & 7570.9 & 3969.7 & 11172.2 & 9166.2 & 8052.9 & 10639.6 \\
\hline Diff (1-2) & Satterthwaite & 7570.9 & 3964.0 & 11177.8 & & & \\
\hline
\end{tabular}

\section{Correlation}

The objective of the study was to determine the effect of the NCA on residential mortgage lending. A correlation analysis of the variables used to test this objective was conducted using the Pearson correlation test. Results of the preNCA period and post-NCA period are presented in Table 3 and Table 4 below. 


\section{Pre-NCA Period Correlation Analysis}

Results for the pre-NCA period in Table 3 show that there is a positive relationship between the number of residential bonds registered and the pre-NCA period $(\mathrm{r}=.704 ; \mathrm{p}>.05)$. These results imply that the number of residential bonds issued increased during that period. There is a strong positive relationship between the value of residential bonds registered and the pre-NCA period $(\mathrm{r}=, 921 ; \mathrm{p}>.05)$, which means that the value of residential bonds increased during that period. There is a positive relationship between the number of registered bonds and the value of residential bonds registered $(r=, 874 ; p>.05)$, suggesting that an increase in the number of residential bonds registered led to an increase in the value of residential bonds registered. There was an increase in the number and value of bonds registered during pre-NCA. Overall, these results confirm that the NCA has had a positive influence on the supply of residential mortgages.

Table 3. Pre-NCA correlation analysis

\begin{tabular}{|c|c|c|c|c|}
\hline & & Date & $\begin{array}{c}\text { Number of residential } \\
\text { bonds registered }\end{array}$ & $\begin{array}{l}\text { Value of residential bonds } \\
\text { registered (Rands) }\end{array}$ \\
\hline \multirow{3}{*}{ Date } & Pearson Correlation & 1 & & \\
\hline & Sig. (2-tailed) & & & \\
\hline & $\mathrm{N}$ & 51 & & \\
\hline \multirow{3}{*}{$\begin{array}{l}\text { Number of } \\
\text { residential bonds } \\
\text { registered }\end{array}$} & Pearson Correlation & $.704^{* *}$ & 1 & \\
\hline & Sig. (2-tailed) & .000 & & \\
\hline & $\mathrm{N}$ & 51 & 51 & \\
\hline \multirow{3}{*}{$\begin{array}{l}\text { Value of residential } \\
\text { bonds registered } \\
\text { (Rands) }\end{array}$} & Pearson Correlation & $.921^{* *}$ & $.874^{* *}$ & 1 \\
\hline & Sig. (2-tailed) & .000 & .000 & \\
\hline & $\mathrm{N}$ & 51 & 51 & 51 \\
\hline
\end{tabular}

\section{Post-NCA Period Correlation Analysis}

Looking at the post-NCA correlation analysis in Table 4, there is a negative correlation between the number of residential bonds registered and post-NCA period $(\mathrm{r}=-.711 \mathrm{p}<.05)$, as the periods in which the NCA was applied scored lower approval ratios than prior to the NCA. There is a negative correlation between the value of residential bonds registered and post-NCA period $(\mathrm{r}=-.631 ; \mathrm{p}<.05)$; there was a drop in the value of residential bonds registered after the implementation of the NCA. There is a strong positive relationship between the number and the value of residential bonds registered $(r=, 992 ; \mathrm{p}>.05)$, suggesting that an increase in the number of residential bonds registered leads to an increase in the value of residential bonds registered.

Table 4. Post-NCA correlation analysis

\begin{tabular}{|c|c|c|c|c|}
\hline & & Date & $\begin{array}{l}\text { Number of residential } \\
\text { bonds registered }\end{array}$ & $\begin{array}{c}\text { Value of residential } \\
\text { bonds registered (Rands) }\end{array}$ \\
\hline \multirow{3}{*}{ Date } & Pearson Correlation & 1 & & \\
\hline & Sig. (2-tailed) & & & \\
\hline & $\mathrm{N}$ & 51 & & \\
\hline \multirow{3}{*}{$\begin{array}{l}\text { Number of residential } \\
\text { bonds registered }\end{array}$} & Pearson Correlation & $-.711^{* *}$ & 1 & \\
\hline & Sig. (2-tailed) & .000 & & \\
\hline & $\mathrm{N}$ & 51 & 51 & \\
\hline \multirow{3}{*}{$\begin{array}{l}\text { Value of residential } \\
\text { bonds registered } \\
\text { (Rands) }\end{array}$} & Pearson Correlation & $-.631^{* *}$ & $.992^{* *}$ & 1 \\
\hline & Sig. (2-tailed) & .000 & .000 & \\
\hline & $\mathrm{N}$ & 51 & 51 & 51 \\
\hline
\end{tabular}




\section{T-TEST}

The objective of the article was to draw a comparison between pre- and post-NCA periods in order to determine if there was a change in residential mortgage lending. Furthermore, the study sought to determine whether the difference in mean is statistically significant. The t-test was performed as presented in Table 5 . The t-test is used when there are two independent samples or categories. From Table 5, it can be seen that $\operatorname{Pr}<0.0001$, which is less than 0.05 . Therefore, the hypothesis that the mean scores for the pre- and post-NCA period are equal is rejected.

Table 5. Variances

\begin{tabular}{c|c|c|c|c}
\hline Method & Variances & DF & t-value & Pr $<|\mathbf{t}|$ \\
\hline Pooled & Equal & 100 & 4.17 & $<.0001$ \\
\hline Satterthwaite & Unequal & 88.657 & 4.17 & $<.0001$ \\
\hline
\end{tabular}

Based on the results presented above, this study has shown that residential mortgages in South Africa dropped after the implementation of the National Credit Act. Similar studies by Pieterse (2009), Pillay (2009) and Rossouw (2008) also concluded that the NCA has impacted the South African market positively, be it vehicle financing, mortgages or micro lending, implying that cases of reckless credit granting by lending institutions have been slowed down.

\section{CONCLUSION}

The demand for residential accommodation is South Africa has been and still remains a confounding problem. Banks and financial institutions engaged in mortgage lending to non-deserving households which resulted in high levels of default. In response to the escalating default rates, government promulgated the National Credit Act in 2007. The objective of this article was to determine the impact of the NCA on mortgage lending.

Using time series bank data, this study shows that mortgage lending to households decreased after the promulgation of the NCA. It is safe to conclude that the regulation of the credit market using the NCA has reduced the banks' portfolio holdings of household mortgage bonds thereby reducing their revenues. However, the NCA has brought sanity to the credit market due to the stringent criteria put in place to prevent reckless lending.

Recommendations for further research are the following:

- This study was based only on the effect of the NCA on banks. Future research could examine its effect on consumers.

- This study was based only on banks, but it would be interesting to determine the effect of the NCA on the property market.

- This was a quantitative research study. An in-depth qualitative as well as quantitative study could be carried out in future.

The NCA is positive legislation and its purpose is to protect consumers against reckless lending and to create a fair credit market. This means that regulation must be fair and trading in the market must be efficient and competitive. The findings of this study will positively contribute to the academic field of knowledge and provide new ideas to the banks and the NCA.

\section{ACKNOWLEDGEMENTS}

This paper is based on Master's research project by the first author entitled: "The impact of the National Credit Act on residential mortgage lending in South Africa." Correspondence should be addressed to Joseph Chisasa at UNISA, Private Box 392, Pretoria 0003. 


\section{AUTHOR BIOGRAPHIES}

Ms. Catherine Boonzaaier is an Administrator at the University of South Africa. She holds a Master of Commerce Degree in Business Management from the University of South Africa. Her research interests are in financial management.

Professor Joseph Chisasa is an Associate Professor of Agricultural Finance and Banking in the Department of Finance, Risk Management and Banking. He has published in international journals that include: Applied Business Research, International Business and Economics Research Journal, Journal of Agribusiness and Rural Development, among others. His research interests are agricultural finance and economics, banking and credit management.

\section{REFERENCES}

Boleat, M. (2003). Regulation of mortgage lending institutions. Housing Finance International, 1-9.

Credit Act's impact on home loans. (2007, May17). Retrieved February 22, 2016, from http://www.theforumsa.co.za/forums/showthread.php/1242-Credit-Act-s-impact-on-home-loans

Croucher, J. S. (2010). Introductory mathematics and statistics. (5th ed.). New York: McGraw-Hill.

Davel, G. (2013). Regulatory options to curb debt stress. CGAP.

Department of Trade and Industry (DTI), Republic of South Africa. (2004a). Consumer credit law reform: Policy framework for consumer credit. Pretoria.

Department of Trade and Industry (DTI), Republic of South Africa. (2004b). Credit law review: Setting the scene. Pretoria.

Duca, J. V., Muellbauer, J. \& Murphy, A. (2010). Housing markets and the financial crisis of 2007-2009: Lessons for the future. Journal of Financial Stability, 6, 203-217.

Flanagan, M. (2012). Mortgage markets: Regulation and intervention. In: S.J. Smith, M. Elsinga, L. Fox O’Mahony, S.E. Ong, S. Wachter, K-H. Kim, editors. [E-book]. International encyclopedia of housing and home. Oxford: Elsevier, 4, $507-517$.

Freybote, J. \& Karoly, V. (2008). Secondary mortgage markets in South Africa. In D. Ben-Shahar, C. K. Y. Leung \& S. E. Ong, editors. Mortgage markets world-wide. Oxford: Blackwell.

Gilbert, A. (2004). Helping the poor through housing subsidies: Lessons from Chile, Columbia and South Africa. Habitat International, 28(1), 13-40.

Goodwin-Groen, R.P. \& Kelly-Louw, M. (2006). The National Credit Act and its regulating in the context of access to finance in South Africa. FinMark Trust.

Ho, G. \& Pennington-Cross, A. N. (2008). Predatory lending laws and the cost of credit. Real Estate Economies, 36, $175-211$.

Kajimo-Shakantu, K. \& Evans, K. (2006). The role of banks in the provision of low-income housing finance in South Africa: Can they play a different role? International Journal of Strategic Property Management, 10, 23-38.

Kashyap, A., Rajan, R. \& Stein, J. (2008). The global roots of the current financial crisis and its implications for regulation. Paper presented at Fifth Central Banking Conference. Frankfurt am Main, Germany. Retrieved February 12, 2013, from http://www.ecb.europa.eu/pub/pdf/other/euroattenen2009en.pdf?6ca2c8ad670dc32eecd6ba34120c80b5

Kolb, R. W. (2011). The financial crisis of our time. Financial Management Association Survey and Synthesis Series. Oxford University Press.

Lemanski, C. (2012). Housing and the state in South Africa. In: S.J. Smith, M. Elsinga, L. Fox O'Mahony, S. E. Ong, S. Wachter, K-H. Kim, editors. [E-book]. International encyclopedia of housing and home, Oxford: Elsevier, 4, 337-339.

Le Roux, F. E. (2011). The provision of low-cost housing in South Africa: A wicked problem with a systems theory solution. Master's in Philosophy, University of Stellenbosch.

Lightstone Property. (2013). E-mail message to researcher.

Luttig, H. H. (2010). An evaluation of the South African National Credit Act and the implications for credit users. Master's in Business Administration, University of Stellenbosch.

Minister of Trade and Industry. (2005). Address on 13 October.

Mizen, P. (2008). The credit crunch of 2007-2008: A discussion of the background, market reactions, and policy responses. Federal Bank of St Louis, 90(5), 531-67.

Mortgage performance initial findings for comment Retrieved April 10, 2015, http://www.housingfinanceafrica.org/wpcontent/uploads/2015/04/Findings-Performance-Analysis-of-FSC-loans

Mould, K. (2008). Tacit responsibilities assigned to the drafter of a credit agreement by the National Credit Act 34 of 2005 with particular emphasis on contractual consensus. A critical analysis. Journal for Juridical Science, 33(2), $109-127$.

Okpala, D. C. I. (2012). House building industries: Africa. In: S.J. Smith, M. Elsinga, L. Fox O’Mahony, S. E. Ong, S. Wachter, K-H. Kim, editors. [E-book]. International encyclopedia of housing and home. Oxford: Elsevier, 4,182-186.

Pieterse, H. C. (2009). The National Credit Act of South Africa and the motor finance sector. Master's in Business Leadership, University of South Africa. 
Pillay, A. \& Naude, W.A. (2006). Financing low-income housing in South Africa: Borrower experiences and perceptions of banks. Habitat International, 29(3), 872-885.

Pillay, S. (2009). The paradoxical effect of the National Credit Act on the residential property market in South Africa. Master's in Business Administration, University of KwaZulu-Natal.

Porteous, D. (2005). Setting the context: South Africa. Housing Finance International, 1, 34-39.

Rossouw, Z. (2008). The impact of the National Credit Act on micro lending sales in a bank in South Africa. Master's in Business Administration, University of Pretoria.

South Africa. (2005). National Credit Act 34 of 2005. Pretoria: Government Printer.

Stecker, J. H. (2009). Impact of the 2008 economic crisis on the insurance industry - first impressions. Journal of Financial Service Professionals, 63(2), 71-76.

Stoop, P. N. (2009). South African consumer credit policy: Measures indirectly aimed at preventing consumer over-indebtedness. South African Mercantile Law Journal, 1, 365-386.

Tomlinson, M. R. (2002). Efforts and errors: South Africa's search to extend housing finance to low-income households. Housing Finance International, 17(2), 8-14.

Tomlinson, M. R. (2007). The development of a low-income housing finance sector in South Africa: Have we finally found a way forward? Habitat International, 31(1), 77-86.

United Nations. (1948). Universal Declaration of Human Rights. Retrieved August 14, 2015, from http://www.supremecourt.ge/files/upload-file/pdf/act3.pdf.

Walker, I. (2010). Research methods and statistics. London: Palgrave Macmillan.

Whittaker, M. (2008). South Africa's National Credit Act: A possible model for the proper role of interest rate ceilings for microfinance. Northwestern Journal of International Law \& Business, 28, 561-582. 


\section{NOTES}

